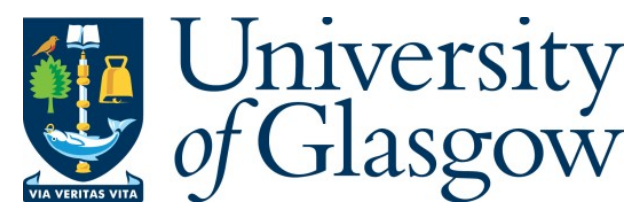

Read, B. and Leathwood, C. (2020) Casualised academic staff and the lecturer-student relationship: shame, (im)permanence and (il)legitimacy. British Journal of Sociology of Education, 41(4), pp. 539-554.

(doi: $10.1080 / 01425692.2020 .1748570)$

This is the Author Accepted Manuscript.

There may be differences between this version and the published version. You are advised to consult the publisher's version if you wish to cite from it.

https://eprints.gla.ac.uk/212743/

Deposited on: 25 March 2020

Enlighten - Research publications by members of the University of Glasgow http://eprints.gla.ac.uk 


\title{
Casualised Academic Staff and the Lecturer-Student Relationship: Shame, (Im)permanence and (II)legitimacy
}

Barbara Read, University of Glasgow

Carole Leathwood, London Metropolitan University

This is a post-peer-review, pre-copyedited version of an article accepted for publication in British Journal of Sociology of Education.

\begin{abstract}
This paper is based on findings from an email interview study with 20 academics (17 women, 3 men) in the UK on short-term, insecure or 'casualised' contracts. The paper focuses on their perceptions of the effect their contract status has on the lecturer/student relationship: particularly in regard to student perceptions of their legitimacy and status. Using a poststructuralist theoretical lens, we explore lecturers' concerns or anxieties as to whether they may be interpreted as less legitimate than permanent staff; and the emotional labour involved in the work done to 'cover' for the difficulties that a lecturer's contract status causes for the quality of their teaching content and organisation. We also explore the considerations of some participants to voluntarily 'disclose' their status to students and the possibilities of such acts as a form of resistance to dominant discourses of the legitimate academic.
\end{abstract}

Wordcount: 7861 words including bibliography

\section{Acknowledgements}

We would like to express our deepest thanks to all those who participated in this study and to the anonymous reviewers for their very helpful comments on an earlier draft. 
This paper focuses on findings from a study of academics in the UK on short-term, insecure or casualised contracts, and their perceptions of the effect their contract status has on the lecturer/student relationship: particularly in regard to student perceptions of their legitimacy and status. In recent years, the casualization of labour within academia has increased, even in the richest countries of the Global North (Gupta, Habjan, and Tutek, 2016). In the UK, the Universities and College Union (UCU) concluded that as of 2014 'at least 54\% of all academic staff and $49 \%$ of academics teaching in our universities are on an insecure contract' (UCU, 2016, 4), with women and/or minority ethnic academics more likely to be on casualised contracts than their white male peers (ECU, 2016).

A growing number of studies have focused on the experiences of this group of academics and the effects of such insecurity, including the anxieties of lack of dependable income and benefits, lack of mentoring, support and capacity-building, inability to plan for the future, and more the subtle effects on self-esteem and professional identity of ongoing 'micro' inequities of exclusion and marginalisation in everyday academic life (Ylijoki, 2010; Leathwood and Read, 2013; Acker and Haque, 2017; Read and Leathwood, 2018).

Building on such work, the contribution of this article lies in the particular attention given to the under-researched area of the effects of casualised contracts specifically on the teacherstudent relationship, which has so far been the focus of relatively few empirical studies (in the USA Street, Maisto, Merves, and Rhoades 2012; in the UK Lopes and Dewan, 2014; and in Australia Klopper and Power, 2014; Lama and Jouillie, 2015). Further, this work has generally not made recourse to social theory in order to understand the complexities of such dynamics. Of the four studies we have found that have focused on this issue, only one (Lopes 
and Dewan, 2014) apply a specific theory (labour process theory) to understand the data they present. We aim to add significantly to the current body of work in this area in applying an alternative poststructuralist theorisation that allows for an in-depth focus on the fluid, contextual dynamics of power that can characterise this complex relationship. The paper explores academics' perceptions of the impact of their casualised status on their perceived legitimacy as 'professional' academics; how this impacts on the ways they manage and perform their academic subjectivities in their relationships with their students and the university; and the ways in which dominant discourses are accommodated, subverted or resisted. Poststructuralist theory gives us a lens through which to analyse these complexities and explore how particular social discourses underpin/work to legitimise these dynamics. In conducting this work we hope to contribute new empirical knowledge to international debate across Europe, the US, Australia and other high income country contexts on the impacts of casualization in the sector on academic life and work and the student-teacher relationship, thus potentially facilitating challenge and change to what is increasing becoming the 'new normal' of the casualised university.

\section{Social Dynamics of Power in the Lecturer/Student Relationship}

Much has been written on the changing nature of the lecturer/student relationship in academia with the pervasive rise of neoliberal influence on academic cultures and practices.

Traditionally lecturers are perceived as holding a high level of status and authority in relation to their students. Bourdieu for example notes that the cultural and symbolic capital acquired by the tutor through the status of their occupation and qualifications gives their communications a greater legitimacy than the student (Bourdieu, 1991). Notably, the discursive construction of the typical academic was historically (and remains, implicitly) the figure of the white, middle- or upper-class male, with no caring responsibilities (Leathwood, 
2013), potentially influencing the ways in which lecturers are interpreted by students (and other staff) as more or less authentic or legitimate in their roles.

In recent years sociological research has also pointed to a significant disruption to the traditional authority of the lecturer as a result of the rise of neoliberal policies and practices that emphasise student entitlement as consumers of knowledge, with such knowledge perceived as a commodity to be sold by the university (Marginson, 1994; Tomlinson, 2017). Arguably, however, this perception of student entitlement is one that tends to fit most closely with - and thus more comfortably adopted by - those with middle-class (and white, masculine) subject positions (Skeggs, 2004; Reay, David, and Ball 2005). Moreover, as Brooks (2017) has recently pointed out, the discursive construction of the student in contemporary HE policy tends to portray a less 'empowered' conception of students as vulnerable to making 'wrong' decisions, dependent and 'childlike'. Nevertheless, traditional notions of the authority of the lecturer in relation to the student may potentially be challenged by the growing proportion of teaching conducted by academics who are on temporary, insecure contracts and who are arguably positioned as second-class citizens in academia.

\section{The intelligibility of the academic subject and the discursive construction of legitimacy}

In order to analyse our participants' constructions of self and their perceptions of the student/lecturer relationship, we draw on a Foucauldian theoretical framework (Foucault, 1977, 1981) influenced by other poststructuralist writers such as Butler $(1990,2004)$ and Ahmed (2004). We thus focus here on subjectivity rather than identity - that is, the dynamics of becoming a subject that is intelligible as such to self and others. Such a process is not, of course, arbitrary - at any particular cultural context or moment a multiplicity of discourses 
can be drawn on from which to make a subject position socially intelligible to others (Butler, 2004). Most often the discourses drawn on will be those dominant discourses that work as regulatory norms - mechanisms of power that help to legitimise what is seen as normal, and also what is judged as alternative or different to the normal (Foucault, 1977; Butler, 2004; Davies et al., 2006). In the case of the academic self, this includes dominant (gendered, classed and racialised) discourses concerning the natural or ideal academic, woven with wider dominant discourses concerning what counts as the typical or ideal, legitimate professional (Thomas and Davies, 2002; Morley, 2013; Coate and Kandiko Howson, 2016). We will be arguing here of the persistence, despite widespread changes in the sector, of a narrative in academia that contributes to the perceived legitimacy of dominant discourses of the academic - the notion of professional legitimacy through the perceived status of permanence.

Universities as institutions have long accentuated cultural signifiers of age and seeming permanence to signify their cultural legitimacy as long-established institutions producing reliable, credibly authentic knowledge: shown for example in the Victorian era choice of neogothic or neoclassical architectural styles; the performance of ritualised traditions such as graduation ceremonies, and the promotion of a narrative story of the university's history (Leathwood and Read, 2009). Similarly, markers of an individual academic's prestige and status in an institution, such as a dedicated office space and one's 'name on the door', work to spatially signify the legitimacy of the individual to be associated with, or 'own', part of the space of the university - and thus be linked to the credibility and perceived authenticity of the university itself. 
The consequences of not being able to access such signifiers of authenticity can lead to a concern with the validity of one's presentation of self to others that can trigger discomfort, embarrassment and shame. In conceptualising such emotions, we note the rich tradition of feminist and other critical work on the place of emotion in education, including hooks' (1994) articulation of passionate and embodied teaching, Lynch's (2008) 'care-less' academy and Walkerdine, Lucey and Melody's (2001) insistence on the importance of working with emotion to understand contemporary subjectivity, to name just some contributions to this field. Recognising the rich diversity of sociological and psycho-social work on emotion, Hey and Leathwood (2009, p. 22) note Clarke's (2006) insistence that rather than sticking inflexibly to one position, it is important to 'try to hold onto rather than eliminate the tensions between the biological, the interactional, social constructionism and psycho-analysis' as a way of enhancing a sociological analysis. Our own theoretical position is a broadly poststructuralist one, that sees emotion/affect as both social and embodied and central to subjectivity and subjectification - to the politics of education. In line with Ahmed's (2004) call to explore the social and political dynamics and constitution of such emotions, Burke (2012) describes the shaming techniques of being (mis)recognised as a 'widening participation' student, due to its association with individualised discourses of lack and deficit. Similarly, feelings of discomfort or even shame engender complex considerations of management of self to others amongst our participants, practices of covering or hiding, and also considerations of resistance through disclosure.

\section{Methodology}


We are concerned in this study to explore the ways in which power relations are subjectively constructed, negotiated and challenged by individuals at the micro level in nuanced and sometimes contradictory ways, hence we have chosen to apply a theoretical lens influenced by poststructuralist perspectives outlined above. Such an approach is especially important in the current policy landscape in order to understand and bring attention to the ways in which traditional power relations (between lecturer-student and between lecturers and the institutions that employ them) are increasingly being challenged and reformulated in ways that do not allow for an assumption of clear, enduring hierarchies of power- in particular the assumption that lecturers per se are a privileged, secure and elite group (Bourdieu, 1991).

The fluidity of a poststructural approach to power and subjectivity helps us to meet the main aim of the project from which the data for this paper derives, which was 'To explore the perceptions and experiences of 'casual' academic staff in the UK in regards to the perceived impact (if any) of their employment status on their teaching and pedagogical interactions with students (see also Leathwood and Read, forthcoming). This paper draws on findings specifically relating to the student/lecturer relationship outside of formal classroom teaching, and participants' perceptions of their own academic/professional identities and relationships with their institutions. When analysing these data we were surprised at the strength of a thread running through the data concerning lecturers' concerns relating of the ways others (particularly students) might perceive their legitimacy- and how this influenced their presentation of self in interactions with students. This then has formed the basis of the focus for this paper.

The data we draw on involves qualitative email interviews with 20 participants (17 women and 3 men), conducted between November 2017 and August 2018. All participants were (or 
had been until very recently) employed in temporary, part-time and/or hourly paid contracts, and who taught in some capacity as part of their academic duties. Participants were recruited via academic networks and personal contacts, and were asked if they would like to offer personal contextual information (for a detailed breakdown of this information please see Table 1). Participants primarily identified as white (19 participants) and middle-class (14 participants). The spread of participants in relation to gender, social class and 'race'/ethnicity reflect inequalities that, as we have mentioned above, is repeated in the academic workforce nationally.

\section{[Table 1 here]}

Obtaining data via qualitative interview was considered to be the most effective way of exploring the views of participants and their perceptions of their teaching and learning experiences in HE. Email interviews have increasingly been successfully utilized in social science research (see e.g. Burns 2010) and allow for participants to respond to questions at their own time and pace, and with the ability to edit their written answers before sending to the researcher. We would argue that despite a possible conception that such methods are less authentic than face-to-face interviewing, there is a significant benefit in relation to the greater degree of participant agency in terms of presenting their answers.

After being given information on the nature of the study and assured of anonymity and confidentiality, participants were given a number of open-ended questions via email, sent in two parts. All but three of the participants contributed answers to both stages. Afterwards two participants sent us further emails with further thoughts in relation to the topics covered. In addition, following initial analysis, we sent an additional email following up specifically in 
relation to their perceptions of the level/degree of student awareness of their status and their views or experience around disclosure of their status to students, to which 10 participants replied. The resulting data was rich in volume as well as in terms of quality of content: participants answered an average of 150 words for each of the 15 original and 3 follow-up questions, the briefest average answers given by Nadia (44 words) and Sara (70 words) and the longest average answers given by Zoe (343 words) and Julia (383 words).

We applied a rigorous thematic analytic process, in which initial coding of the data by both researchers were used as a basis for the establishment of broader themes generated in the data. When discussing particular views and experiences from our data, we have attempted to indicate how common such views and experiences are across our participants' answers, and how far they represent minority or alternative viewpoints. We combined this thematic analysis with a poststructuralist analytical approach - specifically a Foucauldian approach that seeks to understand power not as something that is statically held or possessed by individuals, but as discursively produced, fluid and circulating in relation, for example between casualised academics and their more secure colleagues as well as with students (see Foucault, 1988; Arribas-Ayilon and Walkerdine, 2008). This leads to different questions being applied in analysis of our data, relating to the role of discourses in the construction of social meaning. In a close reading of the interview texts we aimed to identify the socially and culturally located discourses that were being drawn on by participants in order to make sense of moments of interaction with others (either instances that had already happened, or their anticipation of future interactions), and the ways they conceived of themselves and others in these interactions. We then aimed to analyse how such discourses gained power/legitimacy, and in what ways can these discourses be understood as maintaining, exacerbating or resisting wider social patterns of inequality and dis/advantage. An important further question 
in this form of analysis was to discern if, in the participants' accounts, alternative discursive constructions were drawn on to make sense of these past and anticipated future interactions, and the participants' own sense of subjectivity in relation to academia. If alternative discourses were drawn on, how far could they be seen to facilitate a challenge or change to dominant and inequitable patterns of power? For example, how far did these constructions involve a challenge to dominant conceptions as to who can be intelligibly recognized as a legitimate academic? In doing so, a number of themes emerged that highlighted the complexities of the effect of contract status on participants' sense of legitimacy within academia and crucially, how far and in what ways they felt their legitimacy may be judged and called into question by others, which we will now go on to relate.

\section{Hiding Status - Covering ....for the Institution or for the Self}

From a poststructuralist perspective, human beings are often motivated by the need to gain recognition by others in order to maintain a sense of stability in an inevitably unstable process of ongoing subjectification (Butler, 2005; see also Burke, 2012). This recognition is constantly negotiated through ongoing instances or 'iterations' of self-performance, in interaction with others. A recurring theme in our data concerned the complexities of these performances, how they are read by others (or at least, how the participants perceive that they may be read by others) and the consequences of potential misrecognition and potential judgements of one's own lack of 'professionalism' and legitimacy.

Foucauldian writers on professionalism have noted how the performance of the professional involves a disciplinary regulation of self that belies the implication of autonomy underpinning normative conceptions of the professional: 'professionals are both the 
instrument and the subject of government, the governor and the governed' (Fournier, 1999: 285). Individuals are, of course, not completely passive in relation to the process of interpretation and recognition that are involved in such (potential or actual) instances of interaction. As Goffman (1959) highlights, individuals aim in interaction to manage the interpretation of others, even if, in poststructuralist conceptions, such acts of management even those 'counter conducts' that challenge dominant discursive 'regimes of truth' (Foucault, 1988) - are themselves discursively constituted rather than acts of fully autonomous individual agency in the modernist sense. A central facet of these performances seemed to focus on whether or not to explicitly hide ones' temporary contractual status from students when interacting with them - demonstrating the pervasive influence of dominant discourses of legitimacy in academia as lying with perceived permanence. Some explicitly discussed how disclosure of one's temporary, insecure status risked being misrecognised as unprofessional - and the pain of this potential evaluation generating a variety of affect from discomfort and embarrassment to shame.

For some, discomfort at openly disclosing their contract status related to a conception that this would reflect poorly on the institution - a seemingly unprofessional disloyalty to the maintenance of institutional legitimacy. Julia reported "it may be 'unprofessional' to discuss the terms of my contract with students. For instance, I may be perceived as 'bad mouthing' the institution!". She goes on to describe how students eventually found out her status when they enquired about future supervision (a lack of ability to provide - or promise - longer term supervision or support, and the subsequent inability to forge strong pedagogical relationships with students, is one factor participants pointed to when discussing the impact of their status on the quality of their teaching and interactions with students - see Leathwood and Read, forthcoming). 
Some participants described being caught in a 'double bind', where 'covering up' for the institution meant that the fault for logistical problems, arising from their contractual status, would be imputed as a lack of professionalism on the part of the individual lecturer. Whilst this dilemma may also be experienced by more established/permanent contract academics, it is likely to be exacerbated by the marginalisation of casualised staff, who often are required to teach on courses already planned and organized by others. A lack of agency in terms of designing or planning courses, and the lack of, or lateness of, information regarding course details, was another key aspects of casualised status that participants brought up as impacting negatively on the nature and quality of their teaching. In particular, this could lead to difficult interactions with students, who expect each lecturer to be fully informed (see Leathwood and Read, forthcoming). Echoing stories from Anderson's (2007) study, Julia talks about her embarrassment at being required to teach to a strict plan but only receiving this plan very late the night before:

I could not refer to what content would be covered at a later date, making it impossible to answer students' questions of: 'When are we going over the assignment?', 'Will we be covering something about X?' This was incredibly embarrassing; it is unprofessional to tell students why you do not know this information, and avoiding telling them meant that you looked like an incompetent teacher (Julia, p/t fixed-term researcher, under 30, white working-class).

Others discussed more personal reasons for avoiding disclosure about their contract status, relating directly to their attempts to avoid misrecognition in terms of their professional 
legitimacy in instances of interactions with students. As with much of the data, the participants' reflections here focus on anticipating how they may be perceived, and how they may or may not be able to manage these moments of interpretation by students, rather than recounting actual moments of interaction. Jennifer states, for example: 'I [...] don't want them thinking I'm not good enough for the university to employ and that reflecting on the way they perceive me and my teaching". Her avoidance of disclosure of her contract status thus reflects an attempt to manage her interpretation/recognition by others. Again, illustrating the speculative, tentative nature of much of the participants' discussion due to the ambiguities surrounding students' knowledge of their status, she goes on to add 'I have this niggling feeling it might make them see my value differently but I haven't got any evidence of this being the case". Highlighting the importance of permanence as a potential legitimizing signifier in one's recognition as an authentic lecturer, Julia discusses similarly that she did not reveal her fixed-term status because:

....I felt it would lead them to view me as less capable of teaching them. Though, I have never articulated this until now. I suppose then that I felt that students may perceive staff on permanent contracts as more capable because they were 'good' enough to land a permanent post (Julia, p/t fixed-term researcher, under 30, white working-class).

The dominance of the discourse of permanency in relation to being a legitimate or 'real' academic is further illustrated below, along with the painful emotions generated even at the possibility of being judged - or misrecognised - as illegitimate. Olivia below highlights the awkwardness and embarrassment that could be involved in such a reading: 
I feel very conflicted about letting students know about my contractual status [...]. A lot of this, if I'm honest, is about passing as a real academic and is therefore a question of pride. I might be concerned that students might not take me so seriously if they know I'm a temporary, disposable and replaceable member of staff - they could start to question my legitimacy or abilities

(Olivia, $\mathrm{p} / \mathrm{t}$ teaching fellow, aged 41-50, white British middle-class)

Again, the tentative language Olivia uses (students 'might not' take her seriously, they 'could' start to question her legitimacy) highlights the complexities of such strategizing participants anticipate but are not sure of what signifiers may lead them to be interpreted as illegitimate. Echoing Jack and Julia's comments above, what does arise strongly is both the degree to which these participants are concerned with how legitimate students perceive them, the strong suspicion that their casual status may have a negative impact - even that they might be considered disposable, and the emotional cost of such ongoing speculation and work of 'managing the self' as a result.

Some participants discussed instances of attempted management of their presentation of self beyond simply avoiding disclosure of their contract status. For example, in a story Jack recounts, the poor quality of his office space led to students directly asking him about his status. He attempted to manage his answer by avoiding telling them he actually worked outside of academia, and instead emphasised his links to the university as a prior postdoctoral fellow. He goes on to discuss his emotional reaction at his contradictory impulses to be honest to his students, but also to cover for the university and guard against his feelings of loss of status in the students' eyes: 
I felt extremely awkward. I strongly feel that the contract between teachers and students should be based on honesty, and [....] being honest didn't seem like the professional thing to do. My own interests were also at stake as I was put in a position of risk in terms of undermining my status as professional teacher in the eyes of the students, and as a good employee in terms of the university, and telling the students the truth about my status, or indeed not doing so, felt like a betrayal of both obligations (Jack, f/t fixed-term lecturer, 31-40, white British middle-class)

Similarly, Zoe, who became visibly upset when teaching a seminar after receiving a rejection for a permanent post, chose not to disclose her status due to her concern over being seen as illegitimate. Instead she explained that she had been 'knocked off balance by some bad news':

I didn't think that they'd understand the seriousness of what had happened and I might lose their sympathy, but also because I thought they might conclude that it was what I deserved because I wasn't a good teacher, as proven by my crying in class.

(Zoe, $\mathrm{f} / \mathrm{t}$ teaching fellow, fixed term at a pre-92 HEI, white British middle-class)

Like Olivia above, and echoing Hacker's description of the act of 'crying on campus' as disruptive of the academic 'rationality shield' (2018, p. 292), Zoe notes here the gendered, embodied, discursive constructions of the legitimate lecturer - someone who is unemotional, who does not disclose personal weakness - and who only then 'deserves' permanent status (see also Leathwood and Hey, 2009). 
For these lecturers, the legitimacy of their position in the eyes of their students, and thus their authority in terms of the lecturer-student relationship, feels as insecure, ungraspable, fleeting and contextual as other aspects of their working life. The status of the participants quoted in this section certainly do not seem to fit the traditional conception of a fixed hierarchical relationship between (permanent) expert lecturer and (temporary) novice student. Participants in most cases are speculating as to how their students could interpret them if their status was disclosed. This then begs the question as to how far the traditional student-lecturer dynamic is challenged if only one party is aware of a potential shift in the dynamic - although for the lecturers involved, the anxieties over such considerations and the mental and emotional costs of covering seem all too palpable in their effects.

The uncertain guessing game discussed by these participants as to students' perceptions of their legitimacy adds to the wider uncertainties generated by the 'panoptic gazes' infusing contemporary neoliberal academia (Thiel, 2019, p.538). In explaining the effects of hierarchical observation as a form of disciplinary power, Foucault $(1977, \mathrm{p} .170)$ used the analogy of panopticon prison design - where prisoners were never sure whether or not they were being observed, leading to a constant self-regulation of behavior just in case. Ball (2003) notes the uncertainties generated by the disciplinary techniques of impending audit and performance review and the effects on teachers, who are never sure whether their behavior or interactions with students at any single time will end up contributing to a negative judgement of their own (and/ or the institution's) quality. Similarly, lecturers in HE are never certain whether the normalising judgements of students will contribute to a poor performance evaluation in for example, student representative reports, course evaluations, and large-scale surveys such as the UK's National Student Survey (Thiel, 2019). The 
addition of the panoptic gaze of the student to that of management may imply a greater status and authority for the student 'voice'. However, as Thiel (2019) argues, in these circumstances ultimately the "students fulfill the panoptic gaze on behalf of university management" (p.545), providing quantitative, auditable measures of performance by individual lecturers, and encouraging the perception that the success or failure of teaching in higher education solely rests on the quality of performance of the individual lecturer. And, as we have noted, such judgements of lecturer quality are often normalised judgements, constructed through the lens of dominant discourses as to the ideal academic, including potentially an assumption that legitimate lecturers are those with permanent contracts. For participants in our study, the uncertainty as to whether students may question their legitimacy due to their contract status adds another layer to the already existing anxieties felt across sector staff that are generated by neoliberal techniques of audit and appraisal (Leathwood and Read, 2013).

\section{Voluntary Disclosures}

As noted above, Butler (1993) discusses how aspects of identity, such as gender, or a professional identity such as the academic, are constituted only as they are being performed in specific moments of interaction. Our attachment to the need to be socially recognised by others lends itself to conservative reiterations of (often socially normative or normalised) presentations of self (Hey and Leathwood 2009) - in the context of this paper the normalised presentation of the legitimate, professional academic as permanent. Nevertheless, the necessarily constantly repetitious iterations of such performances also generate the possibility of change and subversion to these dominant normalised presentations. Some of our participants discussed voluntarily disclosing their status - and the degree to which this was a 
considered move to challenge normalised conceptions of what counts as being 'legitimate' in academia.

The potential risks of such disclosure are illustrated in Jane's consideration to disclose her status at only one of the two universities in which she worked. She felt that discussing her status implied a critique of the university that she only felt able to do at an institution where she felt more secure:

I think this is largely because [University A] has been my home institution for several years (as a PhD student as well as sessional tutor) and I know that I have many friends and allies here, so I feel more able to be open and/or criticise the casualised system than at [University B] where I was more isolated, and was solely focused on showing up and doing a good job in the hopes of being given more work in the future (Jane, p/t hourly paid tutor, under 30, white British middle-class).

For Jane, then, disclosing her status - at least at one institution - could be seen as a way of resisting the deficit individualizing discourse of casualised lecturers that implies that temporary lecturers are just 'not good enough' to become permanent. Instead, by discussing her status she is able to critique the policy and strategy of the university itself. Similarly, some participants discussed how the recent strike by members of the University and College Union (UCU) across the UK provided an arena to discuss the issue more openly, depersonalising it by viewing the subject on a national level. Olivia recounts "I noticed a few of my students turned up at demonstrations during the strike and were party to conversations about contracts". However she was discouraged by many of the comments by students on social media that she described as very transactional - "they are paying lecturers to deliver 
their teaching and feel affronted when those lecturers don't deliver" - demonstrating at least in these instances echoes of the consumerist discourse of student entitlement.

Zoe recounts an incident where an instance of disclosure did not have the effect of a 'teachable moment' regarding a critique of HE policy on casualisation. After telling the student she was on a fixed-term contract, the student then went on to ask her what she was 'planning to do afterwards'. Zoe was surprised that an otherwise politically attuned student perceived that Zoe's position implied some sort of choice (none of our participants indicated that they had actively chosen their casualized contract status):

.....as if I'd chosen a fixed-term job because I was just planning to do it for a short while before doing something else. I think because she's in a mode of thinking about going to university, doing some temporary work, having a gap year, she didn't quite understand how temporary contracts impact your life when you're out of your late teens/early twenties. [...] I think her lack of awareness, as a 'political' student, speaks to a wider lack of awareness among students about what it means to be on a temporary contract

(Zoe, f/t teaching fellow, fixed term, white British middle-class)

For others the strike and other periods of activism gave more successful chances to discuss the situation with students by socially locating it as a policy rather than (merely) a personal issue: 
in the lead up to the strike I did discuss this [her contract status] [...]. The students would ask me whether I was going on strike and I would explain the reasons I was. I talked about pensions but tried to give them some idea about conditions in HE including precarious contracts. To do this I asked students to guess how long they thought my contract was. They were always shocked to hear it was only 6 months at a time (Caroline, f/t fixed term lecturer, under 30, white British working-class)

[University B] has a larger presence of activism and raising awareness of casualisation, which has meant that I have had more opportunities to raise this issue with students. For example, in 2016 I asked them to sign a petition that demanded for better rights for casual teachers. This had been reported in the student newspaper and I also had a very comfortable relationship with those particular students, so I felt no uneasiness about raising it with them. They were very receptive. I also know that some students follow my twitter account, where I feel able to be a little more 'candid' and open about my status. I do so with an awareness that some students will see this and I think it's important that students are aware of the working conditions of their teachers, as I feel university management are more likely to pay attention to criticisms of students (the fee-payers) than of casual workers

(Jane, p/t hourly paid tutor, under 30, white British middle-class).

Sara and Caroline also explicitly discuss disclosing their status to students as a means of discussing the policy picture of HE and wider issues of social precarity:

I did a lecture on financialization and austerity, as part of this lecture I had some slides on zero-hours contracts, and the 'uberfication' of jobs. I gave examples of 'obvious' 'sports 
direct' ${ }^{1}$ models in industry but then also went to give some 'not so obvious' examples of casualization in higher education (including disclosing my own status) and aeroplane pilots

(Caroline, f/t fixed term lecturer, under 30, white British working-class)

Importantly, in the context of a discourse imbuing the status of 'casualised' with a somehow shamefully questionable legitimacy on the part of the lecturer - combined with a dominant discourse of the 'rational' impersonal academic, Sara specifically discusses a strategy of openness that she labels 'anti-shame':

I've been quite open with them about not knowing if I'll be here at all next year. I do discuss with them explicitly, but I am pretty naturally direct and anti-shame, and I can see how other people might not be comfortable with that. Our students are quite politically aware on the whole though, so I feel like (esp post-strike) they're aware of the issues (Sara, p/t hourly paid Teaching Associate, 31-40, white/Jewish middle-class)

An anti-shame position thus explicitly runs counter to the anticipated (and socially expected) psychosocial affects generated by being evaluated as insufficiently authentic according to dominant discourses of the typical or ideal academic. This positioning, rejecting the discursive construction of the casualised academic as somehow less legitimate, has much in common with academics who refused to be shamed by being judged not suitable to be entered into the then UK Research Assessment Exercise and who established a Facebook site labelled the 'RAE Rejects Group' (Corbyn, 2007). Leathwood and Hey (2009) note that "by

\footnotetext{
${ }^{1}$ 'Sports Direct' is a high street retailer that has been strongly criticised for what a 2016 UK Government Committee report referred to as 'appalling working practices' - see: https://publications.parliament.uk/pa/cm201617/cmselect/cmbis/219/21902.htm
} 
'outing' themselves as 'rejects', these academics have opened up a new space from which to challenge and resist" (437).

Indeed, whilst some in our study felt unwilling or unable to disclose their status to students in any circumstances, others felt more comfortable in utilising personal disclosure as a way of socially locating the issue of casualisation in the sector and indeed wider social inequities in relation to precarity. This then can be seen as an alternative subversive form of resistance or challenge conducted in some cases in addition to direct involvement in union action (direct involvement in union action was discussed by seven participants, with a further two making explicit supportive comments to this action). Although this is a small sample, it makes sense to assume (and we can see from Jane's experience above) that these resistances to dominant discourses of the professional, legitimate, authentic lecturer are more easily managed in institutions where one feels more secure.

\section{Conclusion}

Our use of a poststructuralist approach has allowed us to add a new element to current work on the pedagogical impacts of casualisation in the HE sector. In particular it provides a lens through which to elucidate the complex ways in which the casualised status of lecturers can have demonstrable effects, particularly in terms of the emotional labour involved in the work done to cover for the difficulties that a lecturer's contract status produces in terms of the quality of their teaching and relationships with students. Key pedagogical difficulties brought up by participants concerned a lack of ability to build longer-term knowledge of/relationship with the students they taught; a lack of involvement in planning or constructing courses on which they taught, and delays in being given course content or information, compounded by the emotional labour of attempting to hide such difficulties from students. 
Hiding these difficulties can ultimately work to support a conception that the success or failure of a course is primarily down to the qualities and abilities of the individual lecturer, measured and audited through technologies such as student course evaluations and satisfaction surveys. As we have noted, whilst ostensibly offering greater representation for the views of students, these can work as another form of panoptic gaze in the prism of accountability mechanisms that generate anxieties in the sector for a wide range of academic staff (Leathwood and Read, 2013).

For lecturers on casualised contracts, negative feedback by students can have an immediate impact in terms of not having a contract renewed, or work opportunities being withdrawn. And as we have seen, casualised staff in our study also expressed concerns or anxieties that their contract status itself may contribute to a negative conception of their abilities by students - emotions generated by a potential misrecognition of themselves as inauthentic, as not quite legitimate, as 'second class'. Often this was expressed by participants in uncertain terms as a conception students may perceive - perhaps in relation to signifiers of impermanence such as a lack of a designated office space from which to hold student meetings. This can only exacerbate a sense of marginalisation within the institutions in which casualised academics work. Participants' documentation of repeated attempts to gain a permanent contract - and hence, greater 'legitimacy' - at institutions that repeatedly withhold such a status from them, can be seen as an example of Berlant's (2011) discussion of 'cruel optimism' in conditions of late capitalism, an instance whereby an object of desire is dangled as a potential reward and at the same time cruelly withheld. ${ }^{2}$

\footnotetext{
${ }^{2}$ We are grateful to the anonymous reviewers of earlier drafts of this paper for this and other insightful comments and suggestions.
} 
As well as potential concerns about the consequences for their own perceived legitimacy, some were also concerned that 'rocking the boat' in terms of disclosing their status, may imply a criticism of their university employers that could have potentially negative consequences in terms of future employment contracts. As Morrish (2018) notes, the nationwide strikes in the UK HE sector in 2018 have provided new academic and activist impetus to challenge the effects of neoliberalism in the higher education sector. Social media has played a particularly central role in this challenge, providing an avenue of possibilities but also potential risk for individuals who may be viewed by their own institution as harming their reputation (Morrish, 2018). For some in our study, the strikes were an avenue to explore in a less individualised way the consequences of casualization for higher education. A poststructuralist approach allows us to explore the ways in which some participants subvert dominant conceptions of the 'legitimate' academic in instances of interaction with students at the micro level, through alternative performances of the professional self that voluntarily disclose their status, contextualising it in relation to wider social patterns of inequality in the sector.

Our findings point to a need to foster institutional and departmental cultures that are sensitive to the difficulties that new, part-time and temporary staff may face in terms of connection, belonging and collegiality with permanent, full-time and/or established colleagues. This could include simply a greater openness, discussion and reflection on the ways in which 'micro' aspects of academic culture can greatly affect experience and belonging of staff. For example, Yvonne notes: "This research prompted me to highlight to the Head of Education Studies the lack of inclusion/ identity for HPL staff on office doors [in terms of signage], and this was put right immediately $:-$ "'. Beyond this more work needs to be done to understand at a sectoral level the complexities of the effect of contract status on academics' professional 
subjectivities, on teaching, and of the lecturer-student relationship. In particular there is a need for us to utilise approaches that allow us to investigate the subtle and contextualised ways in which such dynamics play out in micro instances of interaction, and through the emotional costs experienced by some casualised staff of guessing games surrounding normalised judgements concerning one's legitimacy to belong, to 'count' as an academic, in contemporary neoliberal contexts.

\section{References}

Acker, Sandra, and Eve Haque. 2017. "Left Out in the Academic Field: Doctoral Graduates Deal With a Decade of Disappearing Jobs." Canadian Journal of Higher Education 47 (3): 101-119. doi:10.1080/13676260701800753.

Ahmed, Sara. 2004. The Cultural Politics of Emotion. Edinburgh: Edinburgh University Press.

Anderson, Valerie. 2007. "Contingent and Marginalised? Academic Development and Parttime Teachers." International Journal for Academic Development 12 (2): 111-121. doi: $10.1080 / 13601440701604914$. 
Arribas-Ayilon, Michael, and Walkerdine, Valerie. 2008. "Foucauldian Discourse Analysis." In The SAGE Handbook of Qualitative Research in Psychology, edited by Carla Willig and Wendy Stainton-Rogers, 91-108. London: SAGE.

Ball, Stephen J. 2003. “The Teacher's Soul and the Terrors of Performativity.” Journal of Education Policy 18 (2): 215-228. doi: 10.1080/0268093022000043065.

Berlant, Lauren. 2011. Cruel Optimism. Durham, NC: Duke University Press.

Bourdieu, Pierre. 1991. Language and Symbolic Power. Cambridge: Polity.

Brooks, Rachel. 2017. "The Construction of Higher Education Students in English Policy Documents.” British Journal of Sociology of Education. Advance online publication. doi: 10.1080/01425692.2017.1406339.

Burke, Penny Jane. 2012. The Right to Higher Education: Beyond Widening Participation. London: Routledge.

Burns, Edgar. 2010. “Developing Email Interview Practices in Qualitative Research.” Sociological Research Online 15 (4): 8. http://www.socresonline.org.uk/15/4/8.html. doi: $10.5153 /$ sro.2232.

Butler, Judith. 1990. Gender Trouble. London: Routledge.

Butler, Judith. (1993) Bodies That Matter: On the Discursive Limits of 'Sex'. London: Routledge. 
Butler, Judith. 2004. Precarious Life: The Powers of Mourning and Violence. London: Verso.

Butler, Judith. 2005. Giving An Account of Oneself. New York: Fordham University Press.

Clarke, Simon. 2006. "Theory and Practice: Psychoanalytic Sociology as Psycho-Social Studies." Sociology 40 (6):1153-69. doi: 10.1177/0038038506069855.

Coate, Kelly, and Camille Kandiko Howson. 2016. "Indicators of Esteem: Gender and Prestige in Academic Work." British Journal of Sociology of Education 37 (4): 567-585. doi: $10.1080 / 01425692.2014 .955082$.

Davies, Bronwyn, Jenny Browne, Susanne Gannon, Lekkie Hopkins, Helen McCann and Monne Wihlborg, 2006. "Constituting the Feminist Subject in Poststructuralist Discourse”. Feminism \& Psychology 16 (1): 87-103. doi: 10.1177/0959-353506060825.

Equality Challenge Unit [ECU]. 2016. Equality in Higher Education: Staff Statistical Report 2016. London: Equality Challenge Unit.

Foucault, Michel. 1977. Discipline and Punish: The Birth of the Prison. New York: Pantheon.

Foucault, Michel. 1981. The History of Sexuality: An Introduction. London: Penguin. 
Foucault, Michel. 1988. "Truth, Power, Self: an Interview with Michel Foucault, October 25, 1982." In Technologies of the Self: a Seminar with Michel Foucault, edited by Luther H. Martin, Patrick H. Hutton and Huck Gutman, 145-162. Amherst, MA: University of Massachusetts Press.

Fournier, Valerie. 1999. “The Appeal to 'Professionalism' as a Disciplinary Mechanism.” Sociological Review 47 (2): 280-307. doi: 10.1111/1467-954X.00173.

Goffman, Erving. 1959. The Presentation of Self in Everyday Life. London: Penguin.

Gupta, Suman, Jernej Habjan, and Hrvoje Tutek. 2016. Academic Labour, Unemployment and Global Higher Education. London: Palgrave Macmillan.

Hacker, Daphna. 2018. “Crying on Campus.” In Feeling Academic in the Neoliberal University: Feminist Flights, Fights and Failures, edited by Yvette Taylor and Kinneret Lahad, 281-300. Basingstoke: Palgrave.

Hey, Valerie, and Carole Leathwood. 2009. "Passionate Attachments: Higher Education, Policy, Knowledge, Emotion and Social Justice." Higher Education Policy 22:101-18. doi: 10.1057/hep.2008.34.

Hodgson, Damian. 2005. "'Putting on a Professional Performance"”: Performativity, Subversion and Project Management. Organization 12 (1): 51-68. doi: $10.1177 / 1350508405048576$. 
hooks, bell. 1994. Teaching to Transgress. London: Routledge.

Juris, Jeffrey S. 2008. "Performing Politics: Image, embodiment, and affective solidarity during anti-corporate globalization protests." Ethnography 9 (1): 61-97. doi: $10.1177 / 1466138108088949$.

Klopper, Christopher J., and Bianca M. Power. 2014. "The Casual Approach to Teacher Education: What Effect Does Casualisation Have for Australian University Teaching?" Australian Journal of Teacher Education 39 (4): 101-114. doi: 10.14221/ajte.2014v39n4.1.

Lama, Tek and Jean-Etienne Joullie. 2015. "Casualization of Academics in the Australian Higher Education: Is Teaching Quality at Risk?" Research in Higher Education 28: 1-11. ISSN: EISSN-1941-3432.

Leathwood, Carole. 2013. "Re/presenting Intellectual Subjectivity: Gender and Visual Imagery in the Field of Higher Education.” Gender and Education 25 (2): 133-154. doi: $10.1080 / 09540253.2011 .590467$.

Leathwood, Carole and Valerie Hey. 2009. “Gender/ed Discourses and Emotional Sub-texts: Theorising Emotion in UK Higher Education.” Teaching in Higher Education 14 (4): 429440. doi: 10.1080/13562510903050194. 
Leathwood, Carole, and Barbara Read. 2009. Gender and the Changing Face of Higher Education: A Feminized Future? Maidenhead: SRHE and Open University Press.

Leathwood, Carole, and Barbara Read. 2013. "Research Policy and Academic Performativity: Compliance, Contestation and Complicity." Studies in Higher Education 38 (8): 1162-1174. doi: 10.1080/03075079.2013.833025.

Leathwood, Carole, and Barbara Read. Forthcoming. "Short-term, short-changed? A temporal perspective on the implications of academic casualisation for teaching in higher education." Forthcoming in Teaching in Higher Education. doi: 10.1080/13562517.2020.1742681.

Lopes, Ana, and Indra A. Dewan. 2014. "Precarious Pedagogies? The Impact of Casual and Zero-hour Contracts in Higher Education.” Journal of Feminist Scholarship 7 (8): 28-42. ISSN: ISSN 2158-6179.

Lynch, Kathleen. 2010. "Carelessness: A Hidden Doxa of Higher Education." Arts and Humanities in Higher Education 9 (1):54-67. doi: 10.1177/1474022209350104.

Marginson, Simon. 1994. Markets in Education: A Theoretical Note. (Melbourne, Centre for the Study of Higher Education, University of Melbourne). 
Morley, Louise. 2013. "The Rules of the Game: Women and the Leaderist Turn in Higher Education." Gender and Education 25 (1): 116-131. doi: 10.1080/09540253.2012.740888.

Morrish, Liz. 2018. "Can Critical University Studies Survive the Toxic University?" Academic Irregularities: Critical University Studies, Discourse and Managerialism, June 8. https://academicirregularities.wordpress.com/2018/06/08/can-critical-university-studiessurvive-the-toxic-university/

Read, Barbara and Carole Leathwood. 2018. “Tomorrow's a Mystery: Constructions of the Future and 'Un/becoming' amongst 'Early' and 'Late' Career Academics.' International Studies in Sociology of Education. Advance online publication. doi: 10.1080/09620214.2018.1453307.

Reay, Diane, Miriam David, and Stephen Ball. 2005. Degrees of Choice: Social Class, Race and Gender in Higher Education. Stoke-on-Trent: Trentham.

Skeggs, Beverley. 2004. Class, Self, Culture. London: Routledge.

Street, Steve, Maria Maisto, Esther Merves, and Gary Rhoades. 2012. "Who is Professor 'Staff' and How Can This Person Teach So Many Classes?' Centre for the Future of Higher Education Policy Report 2. Akron, OH: New Faculty Majority Foundation.

Thiel, Jonas. 2019. “The UK National Student Survey: An Amalgam of Discipline and NeoLiberal Governmentality.” British Educational Research Journal 45 (3): 538-553. doi: 10.1002/berj.3512. 
Thomas, Robyn, and Annette Davies. 2002. “Gender and New Public Management:

Reconstituting Academic Subjectivities.” Gender, Work \& Organization 9 (4): 372-397.

Tomlinson, Michael. 2017. 'Student Perceptions of Themselves as 'Consumers' of Higher Education.” British Journal of Sociology of Education 38 (4): 450-467. doi: $10.1080 / 01425692.2015 .1113856$.

Universities and Colleges Union. 2016. Precarious Work in Higher Education: A Snapshot of Insecure Contracts and Institutional Attitudes.

https://www.ucu.org.uk/media/7995/Precarious-work-in-higher-education-a-snapshot-of$\underline{\text { insecure-contracts-and-institutional-attitudes-Apr- }}$

16/pdf/ucu_precariouscontract_hereport_apr16.pdf

Walkerdine, Valerie, Helen Lucey, and June Melody. 2001. Growing Up Girl: Psychosocial Explorations of Gender and Class. Basingstoke: Palgrave.

Ylijoki, Oili-Helena. 2010. "Future Orientations in Episodic Labour: Short-term Academics as a Case in Point.” Time and Society 19: 365-386. doi: 10.1177/0961463X10356220. 